\title{
Canine Mammary Tumors: Risk Factors, Prognosis and Treatments
}

Benavente M. A., Bianchi C. P. and Aba M. A.

$J$ Vet Adv 2016, 6(8): 1291-1300

DOI: $10.5455 /$ jva.20160916045115

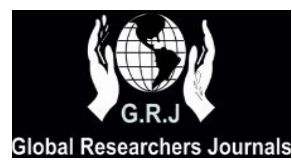




\title{
Review Article
}

\section{Canine Mammary Tumors: Risk Factors, Prognosis}

\section{and Treatments}

\author{
${ }^{*}$ Benavente M. A., Bianchi C. P. and Aba M. A. \\ * Laboratorio de Endocrinología, Centro de Investigación Veterinaria de Tandil (CIVETAN), CONICET, Facultad de Ciencias \\ Veterinarias, UNCPBA, Tandil, Buenos Aires, Argentina.
}

\begin{abstract}
Mammary tumors are the most common neoplasm in the female dog, with a median age of appearance between 9 and 11 years. They may appear as single or multiple nodules, and posterior mammary glands are more frequently affected than anterior glands. Both benign and malignant tumors may occur in the dog, and according to histological criteria, approximately $50 \%$ of the tumors are malignant. Mammary gland tumors tend to be heterogeneous in their pathological characteristics and clinical behavior. Different hormones and growth factors play a key role in the development of this neoplasm, however, the mechanism by which they influence tumor growth and their possible prognostic value are still under study. Besides, new therapeutic options for each particular tumor type are being developed. The aim of this article is to review pathological, prognostic and therapeutic aspects of canine mammary neoplasms.
\end{abstract}

Keywords: Canine, mammary gland, tumors, hormones, prognosis.

${ }^{*}$ Corresponding author: Laboratorio de Endocrinología, Centro de Investigación Veterinaria de Tandil (CIVETAN), CONICET, Facultad de Ciencias Veterinarias, UNCPBA, Tandil, Buenos Aires, Argentina.

Received on: 24 Oct 2015

Revised on: 05 Nov 2015

Accepted on: 20 Aug 2016

Online Published on: 31 Aug 2016

1291 J. Vet. Adv., 2016, 6(8): 1291-1300 


\section{CANINE MAMMARY TUMORS: RISK FACTORS ...}

\section{Introduction}

The mammary gland is a modified apocrine sweat gland, consisting in alveoli and ducts, surrounded by connective tissue, vessels and nerves. Bitches usually develop five pairs of glands, which are called thoracic (2 pairs), abdominal (2 pairs) and inguinal glands (1 pair). Mammary gland of dogs is the most common site for the development of benign and malignant tumors. Benign tumors are usually small, well circumscribed, firm on palpation, and they grow slowly, while malignant tumors are locally invasive, fixed to overlying skin or deep tissues, may be ulcerated and hemorrhagic, and they grow rapidly. Common sites of metastases are regional lymph nodes and lungs, although abdominal organs, bones, and brain can be also affected (Novosad, 2003).

\section{Risk Factors}

The etiology of mammary tumors remains unknown, although several risk factors for their development have been identified, including hormonal, genetic, and nutritional factors.

\section{Hormonal Factors}

Ovarian hormones, mainly estrogens and progesterone, are known to play a key role in the development of canine mammary tumors (CMT). Thus, the age at which the bitch is ovariectomized influences on the risk of developing them. According to the literature, bitches spayed before puberty have $0.5 \%$ of risk, while those spayed after one estrous cycle have an $8 \%$, and those neutered after the second estrous have $26 \%$ of risk (Schneider et al., 1969). Moreover, some reports have shown that estrogens and synthetic progestins, which are commonly used in veterinary practice, seem to enhance tumor formation (Rutteman 1992; Selman et al., 1995; Stovring et al., 1997). Recently, it was observed that levels of steroid hormones in serum and tissue homogenates were higher in bitches with malignant mammary tumors (MMT) compared to benign mammary tumors (BMT), indicating that steroid hormones could act as local growth factors in the malignant types, stimulating their proliferation (Queiroga et al., 2005).
Several studies suggest that, in addition to circulating hormones, their receptors play a central role in mammary tumor formation. The presence of estrogen and progesterone receptors (ER and PR, respectively) in neoplastic mammary tissue has been demonstrated, and their expressions seem to be more frequent in BMT than in MMT (MacEwen et al., 1982; Inaba et al., 1984; Rutteman et al., 1988; Donnay et al., 1995, Martín de las Mulas et al., 2005; Millanta et al., 2005). However, a recent study has found that more than half of both BMT and MMT were negative for ER and PR, indicating lack of correlation between tumor type and ER and PR expression (Toniti et al., 2009). These contradictory results may be related to different numbers and types of tumors analyzed in the studies.

Besides steroid hormones, other hormones and growth factors may influence mammary tumor development. Endogenous progesterone and synthetic progestins can increase the local production of Growth Hormone $(\mathrm{GH})$ in both normal and neoplastic mammary glands of dogs (Selman et al., 1994; van Garderen et al., 1997). Growth Hormone leads to an increase in the concentrations of Insulin-like Growth Factor I (IGFI), which stimulates mammary cell proliferation and act as a local growth factor promoting the development and maintenance of the tumor (Queiroga et al., 2008). Recently, some researchers have proposed that Prolactin (PRL) could have a role in canine mammary tumorigenesis. A study showed that bitches with mammary tumors have higher serum PRL levels than healthy ones, and PRL levels in mammary tissue are greater in MMT than in BMT or normal glands, suggesting that neoplastic mammary tissue could be a source of PRL (Queiroga et al., 2005). Moreover, Michel et al., (2012) observed that PRL receptor expression is lower in MMT than BMT, suggesting that the loss of this receptor may be a characteristic of tumor dedifferentiation.

\section{Genetic Factors}

In addition to hormonal factors, several studies have demonstrated that genetic alterations influence mammary tumor development, and certain breeds appear to display an increased predisposition to 


\section{BENAVENTE ET AL.}

cancer. There are variations between studies regarding the incidence of mammary tumors by breeds. Thus, in Czech Republic, the breeds reported to be at increased risk include the English Cocker Spaniels, Poodles, and Dachshunds (Zatloukal et al., 2005). A retrospective study carried out in Japan has found that the incidence of MMT was lower in small breeds than in others (Itoh et al., 2005). A recent study performed in Sweden has observed that the breeds most frequently diagnosed with this disease were the Leonberger, Irish wolfhound, Doberman, Welsh terrier, and English springer spaniel (Jitpean et al., 2012). In Argentina, the English Cocker Spaniel, Pekingese and German shepherd have been reported as the breeds most frequently diagnosed with mammary tumors (Benavente et al., 2013, Argentina, personal communication).

To determine the extent to which genetic factors may predispose to CMT, many genes have been investigated. For instance, proto-oncogene cerbB-2 encodes for a transmembrane protein, called Epidermal Growth Factor Receptor 2 (EGFR-2 or HER-2), which normally regulates cell proliferation.

However, when it is mutated, HER-2 promotes neoplastic changes in the cells (Gutierrez and Schiff, 2011). Mutation and overexpression of HER-2 has been detected in both benign and malignant CMT (Rungsipipat et al., 1998; Matsuyama et al., 2001). In addition, HER-2 overexpression in MMT has been positively associated with nuclear pleomorphism, high histological grade and mitotic count (Dutra et al., 2004). A recent study indicates that HER-2 contributes to increase the angiogenesis in mammary carcinomas (Carvalho et al., 2013).

Another gene involved in mammary tumorigenesis is p53. The p53 tumor suppressor gene encodes a protein which normally regulates cell cycle and programmed cell death, and its mutations are known to contribute to the carcinogenic process of various organs, including the mammary gland (Greenblatt et al., 1994). In CMT, p53 mutations have been detected in both benign and malignant types (Muto et al., 2000; Lee and Kweon, 2002; Kumaraguruparan et al., 2006).
Alterations of another tumor suppressor gene, called Breast Cancer 1 (BRCA1) have been observed in canine and human mammary cancer. A study has shown that BRCA1 is a nuclear protein, and the loss of its function could lead to an abnormal cytoplasmic distribution (Chen et al., 1995). In the bitch, the absence of nuclear BRCA1 expression is associated with malignant characteristics of the tumors, including high proliferation index and absence of ER $\alpha$ expression, suggesting that it plays a role in the malignant behavior of this neoplasm (Nieto et al., 2003). Abnormalities in the nuclear DNA content have been reported in CMT, being more frequent in malignant than in benign types (Hellmén et al., 1988). In fact, DNA aneuploidy is associated with low survival rates of dogs with a diagnosed MMT (Hellmén et al., 1993).

\section{Nutritional Factors}

Nutritional factors are of special interest due to the ability of adipose tissue to synthesize some steroid hormones. Adipose tissue is an important source of estrogens, owing to its aromatase activity, which converts androgens to estrogens. Increased mammary adipose tissue contributes to exposure of the gland to estrogens, which is known to promote mammary tumorigenesis (Simpson, 1996). Early studies in rodents have observed a close relationship between obesity and a high incidence of mammary tumors (Seilkop, 1995), and epidemiological studies in post-menopausal women have demonstrated that obesity is a risk factor for the development of breast cancer (Wu et al., 1999).

According to Sonnenschein et al., (1991), the risk of developing mammary tumors in the bitch is lower if they have been thin at 9-12 months of age. In addition, obesity at one year of age or one year prior to the diagnosis of the mammary tumor is related to an elevated incidence, and the intake of homemade meals, instead of commercial food, is also related to an increased risk (Pérez Alenza et al., 1998).

\section{Oncogenesis \\ Role of Cyclooxygenase Enzyme in}

There are two isoforms of prostaglandin synthases, also called cyclooxygenases - 1 (COX-1) 


\section{CANINE MAMMARY TUMORS: RISK FACTORS ...}

and 2 (COX-2). Cyclooxygenase -1 is a constitutive enzyme that is expressed in many tissues to ensure the synthesis of prostaglandins (PGs), which are necessary for physiological functions. In contrast, COX-2 is undetectable in most normal tissues, but it is inducible by growth factors, tumor promoters and inflammatory process (Smith et al., 1996). In the past few years, numerous studies have demonstrated that COX-2 is involved in tumor development and progression. In fact, $\mathrm{COX}-2$ expression has been found in several forms of human cancer, including carcinoma of colon, breast, and lung (Soslow et al., 2000).

Similarly, COX-2 expression has been detected in several canine cancers, including prostatic carcinoma, oral melanoma, oral schamous cell carcinoma and mammary carcinoma (Mohammed et al., 2004). Overexpression of COX-2 leads to the production of high concentrations of PGs, which have been reported to increase tumor cell resistance to apoptosis, enhance angiogenesis, increase tumor cell proliferation, and induce immunosupression (Fosslien, 2001). In CMT, COX-2 expression was first demonstrated in 2003 by Doré et al., (2003). Further studies showed that MMT have a higher expression of COX-2 than BMT (Queiroga et al., 2007, Dias Pereira et al., 2009), and that this expression differs between histologic types in mammary carcinomas (Heller et al., 2005).

\section{Prognosis}

The knowledge of different factors implicated in the prognosis and survival of bitches with mammary cancer, allows the clinician to establish an adequate treatment and to predict the potential recurrences or metastases. From a clinical perspective, advanced age at the moment of diagnosis is related to a poor disease-free and overall survival after mastectomy. Tumors larger than $3 \mathrm{~cm}$ in diameter, rapid and invasive growth, ulceration of the skin, fixation to underlying tissues, lymph node involvement, and presence of distant metastasis are also related to poor prognosis for the patient (Hellmén et al., 1993; Yamagami et al., 1996a; Pérez Alenza et al., 1997, Ferreira et al., 2009). Regarding pathological parameters, tumor type has been widely studied. Among malignant tumors, patients with sarcomas have the worst prognosis; among carcinomas, patients with anaplastic or solid carcinomas have lower survival rates than those with papillary, tubular or in situ carcinomas (Hellmén et al., 1993, Misdorp et al., 1999). Histological grading of malignant neoplasms also provides prognostic information. One of the most widely used grading systems in humans is the "Elston and Ellis method" (Elston and Ellis, 1991), which has been recently applied in canines (Karayannopoulou et al., 2005). This last system includes three criteria: tubule formation, mitotic count, and nuclear pleomorphism, and the tumors are classified as well differentiated (grade I), moderately differentiated (grade II), or poorly differentiated (grade III), which is associated with the poorest prognosis (Karayannopoulou et al., 2005; Goldschmidt et al., 2011, Peña et al., 2012). Besides, a study has shown that tissue invasion by cancer cells can predict the biologic behavior of the MMT, and the outcome of patients (Sarli et al., 2002).

Cell proliferation index, which is usually determined by the cell cycle related marker Ki-67, has also been associated with prognosis, and high values of Ki-67 immunostaining have been positively correlated with the development of metastasis, low disease-free survival and overall survival rates (Peña et al., 1998; Santos et al., 2013).

Moreover, increased COX-2 expression is significantly correlated with HER-2 overexpression, tumor dedifferentiation and hence with a bad prognosis in bitches (Millanta et al., 2006). More recent studies have found that COX-2 expression is associated with lymph node metastasis at the time of surgery, development of distant metastasis during the follow-up, and poor diseasefree and overall survival (Lavalle et al., 2009; Queiroga et al., 2010).

In the last decade, special consideration has been given to hormone receptor expression and its value as a prognostic factor. Concerning steroid hormone receptors, in humans it is assumed that patients with ER $\alpha$-positive breast cancer have better response to hormonal treatment and therefore, better prognosis, than patients without mammary tumor expression of ER $\alpha$ (Platet et al., 2004). Similarly, a few number of studies in the bitch have 


\section{BENAVENTE ET AL.}

demonstrated that low levels of ER $\alpha$ are associated with increased tumor size, skin ulceration, lymph node involvement, and occurrence of metastasis during the follow-up, thereby indicating that ER $\alpha$ expression may be a marker of good prognosis (Nieto et al., 2000; Martín de las Mulas et al., 2005). More recently, the ER $\beta$ subtype has been detected in human breast cancer, and some authors have proposed a role for ER $\beta$ as a marker of good prognosis (Honma et al., 2008). In the bitch, a study has demonstrated that ER $\beta$ is expressed in normal and neoplastic mammary glands, with higher expression in BMT than in MMT. Furthermore, the expression is higher in complex and mixed histological types of MMT (which are associated with a favorable prognosis) compared to simple types (Martín de las Mulas et al., 2004), showing that ER $\beta$ expression may be a favorable prognostic factor.

Furthermore, in human breast cancer, the expression of PR was found to be more frequent in well-differentiated tumors than in poorlydifferentiated ones, and a positive PR-status correlates with an increase probability of response to tamoxifen, and improves the outcome prediction over ER status alone (Bardou et al., 2003). In the bitch, the population of PR in MMT is more abundant in those with clinical and histological parameters associated with favorable prognosis (Martin de las Mulas et al., 2005), and dogs with MMT expressing PR had significantly higher survival rates than those lacking PR (Chang et al., 2009). Recently, some authors observed that HER-2 over-expression in MMT was positively associated with indicators of poor prognosis in the bitch (Martin de las Mulas et al., 2003; Dutra et al., 2004). However, Ressel et al., (2013) found that bitches with HER-2 over-expressing carcinomas did not present a poorer prognosis than those with HER-2-non-over-expressing tumors. Considering these controversial results, additional studies are required in order to investigate the significance of HER-2 over-expression in MMT. Concerning the relation between genetic alterations and prognosis, mutations in p53 tumor suppressor gene have been associated with significantly shortened survival time for dogs with mammary cancer (Wakui et al., 2001; Lee et al., 2004).

\section{Conventional Therapies and New Treatment Strategies}

Surgery remains the treatment of choice for all dogs with mammary gland tumors; exceptions include inoperable cases - such as inflammatory carcinomas and distant metastasis - and poor general condition. Several techniques have been described, including lumpectomy, simple mastectomy, regional mastectomy, and unilateral or bilateral mastectomy (Novosad, 2003).

The benefits of ovariectomy as a therapeutic option remains unsolved; some studies have shown improved survival time in bitches treated by mastectomy and ovariectomized than those treated by mastectomy alone (Misdorp 1988; Sorenmo et al., 2000). Conversely, other studies have reported that ovariectomy at the time of mastectomy has no effect on the prognosis of CMT (Yamagami et al., 1996b; Morris et al., 1998). A recent study has demonstrated that ovariohysterectomy performed at the time of tumor excision reduces the risk of new tumors by about $50 \%$ among bitches with BMT (Kristiansen et al., 2013).

Regarding adjuvant therapies, chemotherapy is sometimes indicated in bitches with invasive mammary tumors and high risk of recurrences or metastasis. However, no single chemotherapeutic protocol has been reported to be effective in the dog. Based on in vitro studies, doxorubicin has shown antitumor activity in CMT cell lines (Sartin et al., 1993).

An in vivo study tested a chemotherapy protocol based on a combination of cyclophosfamide and 5 - fluouroucil after mastectomy, having a positive influence on diseasefree interval and overall survival time of treated bitches (Karayannopoulou et al., 2001). Another clinical trial comprised the treatment of bitches with MMT, with doxorubicin or docetaxel, but no benefit in overall survival rates was observed (Simon et al., 2006).

Due to the hormonal dependency of this neoplasm, endocrine therapy is an option to consider. In women, hormonal therapy is a wellaccepted adjuvant treatment and improves survival of patients with breast cancer. One of the most commonly used drugs is tamoxifen, a selective estrogen receptor modulator (SERM), which exerts 


\section{CANINE MAMMARY TUMORS: RISK FACTORS ...}

potent antiestrogenic actions in the breast (Platet et al., 2004). However, in the bitch tamoxifen therapy is not advised due to its estrogen-like effects on reproductive organs, thus producing vulvar swelling, vaginal discharge, incontinence, stump pyometra, and signs of estrus (Novosad 2003; Tavares et al., 2010). Further studies are necessary to find an effective drug with minimal side effects.

The presence of PRs in MMT opens the possibility to use PR antagonists as a post-surgery adjuvant therapy. There is one report about the use of a PR antagonist (aglepristone) in bitches with mammary carcinomas, but no beneficial effect was observed (Hermo et al., 2009). A more recent study has shown that aglepristone has inhibitory effects on proliferation of PR positive canine mammary carcinoma cells (Guil-Luna et al., 2011). Therefore, more studies are necessary to prove its efficacy.

In addition, Lombardi et al., (1999) has tested hormonal therapy using Gonadotropin-Releasing Hormone (GnRH) agonists in bitches with hormone-dependent mammary carcinomas, showing a reduction in the size of the tumors, and beneficial effects in relapse-free survival.

Owing to the involvement of COX-2 in tumor development and progression, selective COX-2 inhibitors have been evaluated in the treatment of bitches with MMT. In vitro studies have demonstrated that certain COX-2 inhibitors (piroxicam and meloxicam) are able to inhibit cell proliferation in different canine cancer cell lines, including mammary carcinoma (Knottenbelt et al., 2006). In addition, an in vivo study has shown that bitches with inflammatory mammary carcinoma treated with piroxicam have an improvement in disease stability and better outcome than those treated with traditional chemotherapy (De Mello Souza et al., 2009). Despite the necessity of further studies, COX-2 selective inhibitors should be considered as part of an adjuvant therapy in dogs with mammary cancer.

Recently, antimetastatic effects of the peptide desmopressin (DDAVP) have been investigated. Desmopressin is a synthetic analog of the antidiuretic hormone vasopressin, and a selective agonist for the vasopressin 2 membrane receptor. This peptide has hemostatic and antidiuretic effects, and has been used in the management of diabetes insipidus (Manucci, 1997). Interestingly, DDAVP inhibited experimental lung metastasis of mammary tumor cells in a mouse model (Alonso et al., 1999). In human breast cancer cell lines, DDAVP exhibits moderate antiproliferative effects (Iannucci et al., 2011). Concerning studies on canines, Hermo et al., (2008 and 2011) carried out two clinical trials in bitches with MMT to test the efficacy of perioperative administration of DDAVP after mastectomy. Desmopressin has a significant beneficial effect on disease-free period and overall survival time, and no side effects were observed in any of the patients. Thus, DDAVP seems to be a potent antitumor agent without evident side effects, and its use should be considered in the treatment of bitches with mammary cancer.

\section{Conclusion}

As mammary tumors are hormone-dependent neoplasms, the ovariectomy at an early age is crucial in order to prevent its development, and the necessity to reduce to a minimum the use of contraceptive steroids is also important.

The heterogeneity of mammary tumors makes them highly variable in their biological behavior, which generates the necessity of identifying factors with prognostic or therapeutic value for each particular patient and type of tumor.

In the last decade, advances in oncology research have allowed to discover previously unknown molecules involved in the carcinogenic process, and to develop therapies aimed at blocking these molecules. At present, the most promising therapeutic options are hormone receptor modulators, peptides with antitumor properties, and non-steroidal anti-inflammatory drugs for tumors expressing COX-2. Besides, more information about chemotherapeutic protocols is mandatory in order to find a safe and effective regimen that prolongs the survival time of bitches with mammary cancer.

Finally, in humans, monoclonal antibodies targeted to different molecules have been developed as new therapies to treat advanced breast cancer. Further investigation is required to assess the value of this type of therapy in the treatment of CMT. 


\section{BENAVENTE ET AL.}

\section{References}

Alonso DF, Skilton G, Farías EF, Bal de Kier Joffé E, Gomez DE (1999). Antimetastatic effect of desmopressin in a mouse mammary tumor model. Breast Cancer Res. Treat., 57: 271-275.

Bardou VJ, Arpino G, Elledge RM, Osborne CK, Clark GM (2003). Progesterone receptor status significantly improves outcome prediction over estrogen receptor status alone for adjuvant endocrine therapy in two large breast cancer databases. J. Clin. Oncol., 21(10): 19731979.

Carvalho MI, Guimarães MJ, Pires I, Prada J, Carvalho RS, Lopes C, Queiroga FL (2013). EGFR and microvessel density in canine malignant mammary tumours. Res. Vet. Sci., 95(3): 1094-1099.

Chang C, Tsai M, Liao J, Chan JP, Wong ML, Chang SC (2009). Evaluation of hormone receptor expression for use in predicting survival of female dogs with malignant mammary gland tumors. J. Am. Vet. Med. Assoc., 235(4): 391-396.

Chen Y, Chen C, Riley DJ, Craig Allred D, Chen P, Von Hoff D, Osborne C, Lee W (1995). Aberrant subcellular localization of BRCA1 in breast cancer. Sci., 270(5237): 789-791.

De Mello Souza CH, Toledo-Piza E, Amorin R, Barboza A, Tobias KM (2009). Inflammatory mammary carcinoma in 12 dogs: Clinical features, cyclooxygenase-2 expression, and response to piroxicam treatment. Can. Vet. J., 50(5): 506-510.

Dias Pereira P, Lopes C, Matos AJ, Santos M, Gartner F, Medeiros R, Lopes C (2009). COX-2 expression in canine normal and neoplastic mammary gland. J. Comp. Pathol., 140(4): 247-253.

Donnay I, Rauis J, Devleeschouwer N, Wouters-Ballman P, Leclercg G, Verstegen J (1995). Comparison of estrogen and progesterone receptor expression in normal and tumor mammary tissues from dogs. Am. J. Vet. Res., 56(9): 1188-1194.

Doré M, Lanthier I, Sirois J (2003). Cyclooxygenase-2 expression in canine mammary tumors. Vet. Pathol., 40(2): 207-212.

Dutra AP, Granja NV, Schmitt FC, Cassali GD (2004). CerbB-2 expression and nuclear pleomorphism in canine mammary tumors. Braz. J. Med. Biol. Res., 37(11): 1673-1681.

Elston CW, Ellis IO (1991). Pathological prognostic factors in breast cancer. I. The value of histological grade in breast cancer: experience from a large study with long-term follow-up. Histopathol., 19(5): 403-410.

Ferreira E, Bertagnolli AC, Cavalcanti MF, Schmitt FC, Cassali GD (2009). The relationship between tumour size and expression of prognostic markers in benign and malignant canine mammary tumours. Vet. Comp. Oncol., 7(4): 230-235.
Fosslien E (2001). Review: Molecular pathology of cyclooxygenase-2 in cancer-induced angiogenesis. Ann. Clin. Lab. Sci., 31(4): 325-348.

Goldschmidt M, Peña L, Rasotto R, Zappulli V (2011). Classification and grading of canine mammary tumors. Vet. Pathol., 48(1): 117-131.

Greenblatt MS, Bennett WP, Hollstein M (1994). Mutations in the $p 53$ tumor suppressor gene: clues to cancer etiology and molecular pathogenesis. Cancer Res., 54(18): 48554878.

Guil-Luna S, Sánchez-Céspedes R, Millán Y, De Andrés FJ, Rollón E, Domingo V, Guscetti F, Martín de las Mulas J (2011). Aglepristone decreases proliferation in progesterone receptor-positive canine mammary carcinomas. J. Vet. Intern. Med., 25(3): 518-523.

Gutierrez C, Schiff R (2011). HER 2: Biology, detection, and clinical implications. Arch. Pathol. Lab. Med., 135(1): 55-62.

Heller DA, Clifford CA, Goldschmidt MH, Holt DE, Shofer FS, Smith A, Sorenmo KU (2005) Cyclooxygenase-2 expression is associated with histologic tumor type in canine mammary carcinoma. Vet. Pathol., 42(6): 776780 .

Hellmén E, Bergstrom R, Holmberg L, Spangberg I, Hansson K, Lindgren A (1993). Prognostic factors in canine mammary tumors: a multivariate study of 202 consecutive cases. Vet. Pathol., 30(1): 20-27.

Hellmén E, Lindgren A, Linell F, Matsson P, Nilsson A (1988). Comparison of histology and clinical variables to DNA ploidy in canine mammary tumors. Vet. Pathol., 25(3): 219-226.

Hermo GA (2009). Estudio de terapias adyuvantes con antiprogestágenos y agentes antimetastásicos en neoplasias mamarias caninas. Tesis Doctoral. Universidad Nacional de La Plata. Argentina.

Hermo GA, Torres P, Ripoll GV, Scursoni AM, Gomez DE, Alonso DF, Gobello C (2008). Perioperative desmopressin prolongs survival in surgically treated bitches with mammary gland tumours: a pilot study. Vet. J., 178(1): 103-108.

Hermo GA, Turic E, Angelico D, Scursoni AM, Gomez DE, Gobello C, Alonso DF (2011). Effect of adjuvant perioperative desmopressin in locally advanced canine mammary carcinoma and its relation to histologic grade. J. Am. Anim. Hosp. Assoc., 47(1): 21-27.

Honma N, Horii R, Iwase T, Saji S, Younes M, Takubo K, Matsuura M, Ito Y, Akiyama F, Sakamoto G (2008). Clinical importance of estrogen receptor $-\beta$ evaluation in breast cancer patients treated with adjuvant tamoxifen therapy. J. Clin. Oncol., 26(22): 3727-3734.

Iannucci NB, Ripoll GV, Garona J, Cascone O, Ciccia GN, Gomez DE, Alonso DF (2011). Antiproliferative effect of 1-deamino-8-D-arginine vasopressin analogs on human breast cancer cells. Future Med. Chem., 3(16): 1987-1993.

Inaba T, Takahashi N, Matsuda H, Imori T (1984). Estrogen and progesterone receptors and progesterone metabolism 


\section{CANINE MAMMARY TUMORS: RISK FACTORS ...}

in canine mammary tumours. J. Vet. Sci., 46(6): 797803.

Itoh $\mathrm{T}$, Uchida $\mathrm{K}$, Ishikawa $\mathrm{K}$, Kushima K, Kushima E, Tamada H, Moritake T, Nakao H, Shii H (2005). Clinicopathological survey of 101 canine mammary gland tumors: differences between small-breed dogs and others. J. Vet. Med. Sci., 67(3): 345-347.

Jitpean S, Hagman R, Strom Holst B, Hoglund OV, Pettersson A, Egenvall A (2012). Breed variations in the incidence of pyometra and mammary tumours in Swedish dogs. Reprod. Domest. Anim., 47(6): 347-350.

Karayannopoulou M, Kaldrymidou E, Constantinidis TC, Dessiris A (2001). Adjuvant post-operative chemotherapy in bitches with mammary cancer. J. Vet. Med., 48(2): 85-96.

Karayannopoulou M, Kaldrymidou E, Constantinidis TC, Dessiris A (2005). Histological grading and prognosis in dogs with mammary carcinomas: application of a human grading method. J. Comp. Pathol., 133(4): 246-252.

Knottenbelt C, Chambers G, Gault E, Argyle DJ (2006). The in vitro effects of piroxicam and meloxicam on canine cell lines. J. Small Anim. Pract., 47(1): 14-20.

Kristiansen VM, Nodtvedt A, Breen AM, Langeland M, Teige J, Goldschmidt M, Jonasdottir TJ, Grotmol T, Sorenmo K (2013). Effect of ovariohysterectomy at the time of tumor removal in dogs with benign mammary tumors and hyperplastic lesions: a randomized controlled clinical trial. J. Vet. Intern. Med., 27(4): 935-942.

Kumaraguruparan R, Prathiba D, Nagini S (2006). Of humans and canines: Immunohistochemical analysis of PCNA, Bcl-2, p. 53, cytokeratin and ER in mammary tumours. Res. Vet. Sci., 81(2): 218-224

Lavalle GE, Bertagnolli AC, Tavares WL, Cassali GD (2009). Cox-2 expression in canine mammary carcinomas: correlation with angiogenesis and overall survival. Vet. Pathol., 46(6): 1275-1280.

Lee C, Kim W, Lim J, Kang M, Kim D, Kweon O (2004). Mutation and overexpression of p53 as a prognostic factor in canine mammary tumors. J. Vet. Sci., 5(1): 6369.

Lee CH, Kweon OK (2002). Mutations of p53 tumor suppressor gene in spontaneous canine mammary tumors. J. Vet. Sci., 3(4): 321-325.

Lombardi P, Florio S, Pagnini U, Crispino A, Avallone L (1999). Ovarian function suppression with a GnRH analogue: D-ser (But[t]) [6]-Arzgly [10]-LHRH (Goserelin) in hormone dependent canine mammary cancer. J. Vet. Pharmacol. Ther., 22(1): 56-61.

MacEwen EG, Patnalk AK, Harvey HJ, Panko WB (1982). Estrogen receptors in canine mammary tumors. Cancer Res., 42(6): 2255-2259.

Manucci PM (1997). Desmopressin (DDAVP) in the treatment of bleeding disorders: the first 20 years. Blood. 90(7): 2515-2521.

Martín de las Mulas J, Millán Y, Dios R (2005). A prospective analysis of immunohistochemically determined estrogen receptor $\alpha$ and progesterone receptor expression and host and tumor factors as predictors of disease-free period in

\section{8}

mammary tumors of the dog. Vet. Pathol., 42(2): 200212 .

Martín de las Mulas J, Ordás J, Millán MY, Chacón M. de Lara F, Espinosa de los Monteros A, Reymundo C, Jover A (2004). Immunohistochemical expression of estrogen receptor $\beta$ in normal and tumoral canine mammary glands. Vet. Pathol., 41(3):269-272.

Martín de las Mulas J, Ordás J, Millán Y, Fernández-Soria V, Ramón y Cajal S (2003). Oncogene HER-2 in canine mammary gland carcinomas: an immunohistochemical and chromogenic in situ hybridization study. Breast Cancer Res. Treat., 80(3): 363-367.

Matsuyama S, Nakamura M, Yonezawa K, Shimada T, Ohashi F, Takamori Y, Kubo K (2001). Expression patterns of the erbB subfamily mRNA in canine benign and malignant mammary tumors. J. Vet. Med. Sci., 63(9): 949-54.

Michel E, Feldmann SK, Kowalewski, MP Rohrer Bley, C Boos A, Guscetti F, Reichler IM (2012). Expression of prolactin receptors in normal canine mammary tissue, canine mammary adenomas and mammary adenocarcinomas. BMC Vet. Res., 8: 72.

Millanta F, Callandrela M, Bari G, Niccolini M, Vannozzi I, Poli A (2005). Comparison of steroid receptor expression in normal, dysplastic, and neoplastic canine and feline mammary tissues. Res. Vet. Sci., 79(3): 225-232.

Millanta F, Citi S, Della Santa D, Porciani M, Poli A (2006). COX-2 expression in canine and feline invasive mammary carcinomas: correlation with clinicopathological features and prognostic molecular markers. Breast Cancer Res. Treat., 98(1): 115-120.

Misdorp W (1988). Canine mammary tumours: Protective effect of late ovariectomy and stimulating effect of progestins. Vet. Q., 10(1): 26-33.

Misdorp W, Else R, Hellmén E, Lipscomb TP (1999). Histological classification of mammary tumors of the dog and cat. In: World Health Organization international histological classification of tumors of domestic animals, 2nd Edn. Armed Forces Institute of Pathology, Washington D.C.

Mohammed SI, Khan KN, Sellers RS, Hayek MG, DeNicola DB, Wu L, Bonney PL, Knapp DW (2004). Expression of cyclooxygenase-1 and 2 in naturally-ocurring canine cancer. Prostaglandins, Leukotrienes Essent. Fatty Acids. 70(5): 479-483.

Morris JS, Dobson JM, Bostock DE, O'Farrell E (1998). Effect of ovariohysterectomy in bitches with mammary neoplasms. Vet. Rec., 142(24): 656-8.

Muto T, Wakui S, Takahashi H, Maekawa S, Masaoka T, Ushigome S, Furusato M (2000). p. 53 gene mutations occurring in spontaneous benign and malignant mammary tumors of the dog. Vet. Pathol., 37(3): 248253.

Nieto A, Peña L, Pérez Alenza MD, Sánchez MA, Flores JM, Castaño M (2000). Immunohistologic detection of estrogen receptor alpha in canine mammary tumors: clinical and pathologic associations and prognostic significance. Vet. Pathol., 37(3): 239-247.

J. Vet. Adv., 2016, 6(8): 1291-1300 


\section{BENAVENTE ET AL.}

Nieto A, Pérez-Alenza MD, Del Castillo N, Tabanera E, Castaño M, Peña L (2003). BRCA1 expression in canine mammary dysplasias and tumours: relationship with prognostic variables. J. Comp. Pathol., 128(4): 260-268.

Novosad CA (2003). Principles of treatment for mammary gland tumors. Clin. Tech. Small Anim. Pract., 18(2): 107-109.

Peña L, De Andres PJ, Clemente M, Cuesta P, Pérez-Alenza MD (2012). Prognostic value of histological grading in non-inflammatory canine mammary carcinomas in a prospective study with two-year follow-up: relationship with clinical and histological characteristics. Vet. Pathol., 50(1): 94-105.

Peña LL, Nieto AI, Pérez-Alenza D, Cuesta P, Castaño M (1998). Immunohistochemical detection of Ki-67 and PCNA in canine mammary tumors: relationship to clinical and pathologic variables. J. Vet. Diagn. Invest., 10(3): 237-246.

Pérez Alenza D, Rutteman GR, Peña L, Beynen AC, Cuesta P (1998). Relation between habitual diet and canine mammary tumors in a case-control study. J. Vet. Intern. Med., 12(3): 132-139.

Pérez Alenza MD, Peña L, Nieto AI, Castaño M (1997). Clinical and pathological prognostic factors in canine mammary tumors. Ann. Ist. Super. Sanita., 33(4): 581585 .

Platet N, Cathiard AM, Gleizes M, Garcia M (2004). Estrogens and their receptors in breast cancer progression: a dual role in cancer proliferation and invasion. Crit. Rev. Oncol. Hemat., 51(1): 55-67.

Queiroga FL, Alves A, Pires I, Lopes C (2007). Expression of Cox-1 and Cox-2 in canine mammary tumours. J. Comp. Pathol., 136(2-3): 177-185.

Queiroga FL, Pérez-Alenza MD, Silvan G, Peña L, Lopes C, Illera JC (2005). Role of steroid hormones and prolactin in canine mammary cancer. J. Steroid Biochem. Mol. Biol., 94(1-3): 181-187.

Queiroga FL, Pérez-Alenza MD, Silvan G, Peña L, Lopes CS, Illera JC (2008). Crosstalk between GH/IGF-I axis and steroid hormones (progesterone, 17 $\beta$-estradiol) in canine mammary tumours. J. Steroid Biochem. Mol. Biol. 110(1-2): 76-82.

Queiroga FL, Pires I, Lobo L, Lopes CS (2010). The role of Cox-2 expression in the prognosis of dogs with malignant mammary tumours. Res. Vet. Sci., 88(3): 441445.

Ressel L, Puleio R, Loria GR, Vannozzi I, Millanta F, Caracappa S, Poli A (2013). HER-2 expression in canine morphologically normal, hyperplastic and neoplastic mammary tissues and its correlation with the clinical outcome. Res. Vet. Sci., 94(2): 299-305.

Rungsipipat A, Tateyama S, Yamaguchi R, Uchida K, Miyoshi N, Hayashi T (1999). Inmunohistochemical analysis of c-yes and c-erbB-2 oncogene products and p53 tumor suppressor protein in canine mammary tumors. J. Vet. Med. Sci., 61(1): 27-32.
Rutteman GR (1992). Contraceptive steroids and the mammary gland: Is there a hazard? Insights from animal studies. Breast Cancer Res. Treat., 23(1-2): 29-41.

Rutteman GR, Misdorp W, Blankenstein MA, van den Brom WE (1988). Oestrogen (ER) and progestin receptors (PR) in mammary tissue of the female dog: Different receptor profile in non-malignant and malignant states. Br. J. Cancer., 58(5): 594-599.

Santos AA, Lopes CC, Ribeiro JR, Martins LR, Santos JC, Amorim IF, Gärtner F, Matos AJ (2013). Identification of prognostic factors in canine mammary malignant tumours: a multivariable survival study. BMC Vet. Res., 9: 1 .

Sarli G, Preziosi R, Benazzi C, Castellani G, Marcato PS (2002). Prognostic value of histologic stage and proliferative activity in canine malignant mammary tumors. J. Vet. Diagn. Invest., 14(1): 25-34.

Sartin EA, Barnes S, Toivio-Kinnucan M, Wright JC, Wolfe LG (1993). Heterogenic properties of clonal cell lines derived from canine mammary carcinomas and sensitivity to tamoxifen and doxorubicin. Anticancer Res., 13(1): 229-236.

Schneider R, Dorn C, Taylor D (1969). Factors influencing canine mammary cancer development and postsurgical survival. J. Natl. Cancer Inst., 43(6): 1249-1261.

Seilkop SK (1995). The effect of body weight on tumor incidence and carcinogenicity testing in $\mathrm{B} 6 \mathrm{C} 3 \mathrm{~F} 1$ mice and F344 rats. Fundam. Appl. Toxicol., 24(2): 247-259.

Selman PJ, Mol JA, Rutteman GR, van Garderen E, Rijnberk, A (1994). Progestin-induced growth hormone excess in the dog originates in the mammary gland. Endocrinol., 134(1): 287-292.

Selman PJ, van Garderen E, Mol JA, van den Ingh T (1995). Comparison of the histological changes in the dog after treatment with the progestins medroxyprogesterone acetate and proligestone. Vet. Q., 17(4): 128-33.

Simon D, Schoenrock D, Baumgärtner W, Nolte I (2006). Postoperative adjuvant treatment of invasive malignant mammary gland tumors in dogs with doxorubicin and docetaxel. J. Vet. Intern. Med., 20(5): 1184-90.

Simpson ER and Zhao Y (1996). Estrogen biosynthesis in adipose. Significance in breast cancer development. Ann. N. Y. Acad. Sci., 784: 18-26.

Smith WL, Garavito M, DeWitt DL (1996). Prostaglandin endoperoxide $\mathrm{H}$ synthases (cyclooxygenases)-1 and 2. J. Biol. Chem., 271(52): 33157-33160.

Sonnenschein EG, Glickman LT, Goldschmidt MH, McKee LJ (1991). Body conformation, diet, and risk of breast cancer in pet dogs: a case-control study. Am. J. Epidemiol., 133(7): 694-703.

Sorenmo KU, Shofer FS, Goldschmidt MH (2000). Effect of spaying and timing of spaying on survival of dogs with mammary carcinoma. J. Vet. Intern. Med., 14(3): 266270.

Soslow RA, Dannenberg AJ, Rush D, Woerner BM, Khan KN, Masferrer J, Koki AT (2000). COX-2 is expressed in human pulmonary, colonic, and mammary tumors. Cancer. 89(12): 2637-2645. 
Stovring M, Moe L, Glattre E (1997). A population - based case- control study of canine mammary tumours and clinical use of medroxyprogesterone acetate. Acta Pathol. Microbiol. Immunol. Scand., 105(8): 590-596.

Tavares WL, Lavalle GE, Figueiredo MS, Souza AG, Bertagnolli AC, Viana FA, Paes PR, Carneiro RA, Cavalcanti GA, Melo MM, Cassali GD (2010). Evaluation of adverse effects in tamoxifen exposed healthy female dogs. Acta Vet. Scand., 52: 67.

Toniti W, Buranasinsup S, Kongcharoen A, Charoonrut P, Puchadapirom P, Kasorndorkbua C (2009). Immunohistochemical determination of estrogen and progesterone receptors in canine mammary tumors. Asian Pac. J. Cancer Prev., 10(5): 907-911.

Van Garderen E, de Wit M, Voorhout WF, Rutteman GR, Mol JA, Nederbragt H, Misdorp W (1997). Expression of growth hormone in canine mammary tissue and mammary tumors. Evidence for a potential autocrine/paracrine stimulatory loop. Am. J. Pathol., 150(3): 1037-1047.

Wakui S, Muto T, Yokoo K, Yokoo R, Takahashi H, Masaoka T, Hano H, Furusato M (2001). Prognostic status of p53 gene mutation in canine mammary carcinoma. Anticancer Res., 21(1B): 611-6.

Wu AH, Pike MC, Stram DO (1999). Meta-analysis: dietary fat intake, serum estrogen levels, and the risk of breast cancer. J. Natl. Cancer Inst., 91(6): 529-534.

Yamagami T, Kobayashi T, Takahashi K, Sugiyama M (1996a). Prognosis for canine malignant mammary tumors based on TNM and histologic classification. J. Vet. Med. Sci., 58(11): 1079-1083.

Yamagami T, Kobayashi T, Takahashi K, Sugiyama M (1996b). Influence of ovariectomy at the time of mastectomy on the prognosis for canine malignant mammary tumours. J. Small Anim. Pract., 37(10): 462464.

Zatloukal J, Lorenzová J, Tichy F, Necas A, Kecová H, Kohout $\mathrm{P}$ (2005). Breed and age as risk factors for canine mammary tumours. Acta Vet. Brno., 74: 103-109. 